VERTAISARVIOITU

KOLLEGIALT GRANSKAD

PEER-REVIEWED

www.tsv.fi/tunnus

\title{
EKSISTENTIAALINEN RATIONAALISUUS JA MONIÄÄNISYYDEN HALLINTA YRITYSTEN VERKKOSIVUJEN VISIO-, MISSIO- JA STRATEGIATEKSTEISSÄ
}

\author{
Tomi Visakko, Helsingin yliopisto
}

\begin{abstract}
Artikkelissa tarkastellaan eksistentiaaliseksi rationaalisuudeksi kutsuttua semioottista prosessia yritysten verkkosivujen visio-, missio- ja strategiateksteissä. Tavoitteena on ymmärtää, miten teksteissä määritellään julkisesti yrityksen identiteettiä, pyrkimyksiä ja sosiaalisia suhteita. Erityisesti huomion kohteena on se, miten tässä prosessissa hyödynnetään eksplikoitua moniäänisyyttä eli miten teksti mallintaa suhdettaan toisiin ääniin. Analyysi kohdistuu sellaisiin metadiskursiivisiin signaaleihin, joilla osoitetaan diskursiivisten ainesten lähteitä ja keskinäisiä suhteita. Tutkimuksessa on käyty 131 tekstistä läpi joukko intertekstuaalisia suhteita kuvaavia tai presupponoivia morfosyntaktisia rakenteita (puhetta tai ajatusta esittävät että-lauseet ja referatiivirakenteet, lainausmerkit, mukaan- ja mielestä-postpositiolausekkeet, kieltolauseet, kysymyslauseet) ja analysoitu niiden käyttöä erilaisissa tekstuaalisissa rakenteissa. Tyypillisiä moniäänisyyden hallinnan muotoja ovat traditionaalisten ja auktoritatiivisten äänten välittäminen, eri äänten metalingvistinen reflektio ja yhteensovittaminen, yrityksen kannalta positiivisten äänten tarjoaminen rekontekstualisoitaviksi sekä negatiivisten äänten kumoaminen tai neutralisoiminen.
\end{abstract}

Avainsanat: evaluointi, intertekstuaalisuus, metadiskurssi, moniäänisyys, rationaalisuus

\section{JOHDANTO}

Verkkosivustojensa visio-, missio- ja strategiateksteissä yritykset joutuvat määrittelemään identiteettinsä ja intentionsa varsin

Kirjoittajan yhteystiedot:

Tomi Visakko

tomi.visakko@helsinki.fi heterogeeniselle yleisölle. Niiden on sitouduttava julkisesti tekstiin, jossa perustellaan, millaisia päämääriä yritys tavoittelee ja millaisin keinoin, millaisten olettamusten, periaatteiden ja arvohierarkioiden valossa yritys toimii ja millaisissa suhteissa se on toisiin toimijoihin. Kyse on eksistentiaaliseksi rationaalisuudeksi (ks. Kockelman, 2013, s. 129-133, 171-199; Visakko 2018) kutsutun semioottisen prosessin yhdenlaisesta ilmentymästä. 
Eksistentiaalisella rationaalisuudella tarkoitetaan tässä artikkelissa siis identiteettien rakenteen reflektointia ja järkeilyä suhteessa vallitseviin olosuhteisiin hyödyntäen kielenkäytön mahdollistamia merkitysrakenteita ja päättelyprosesseja. Lisäksi visio-, missio- ja strategiateksteissä on kyse markkinoinnista ja maineenhallinnasta: niissä levitetään tarkkaan punnittua julkista kuvausta, jolla pyritään vaikuttamaan toisten asenteisiin. Eksistentiaalisella rationaalisuudella onkin tiivis yhteys idealisointiin: itsestä pyritään välittämään kohdeyleisöille toivotunlainen kuva, mikä edellyttää tekstiin päätyvien ainesten tarkkaa valikointia ja muotoilua monenlaisten kulttuuristen olettamusten valossa (vrt. Visakko 2015). Idealisoinnissa on myös asennoiduttava jollakin tavalla sosiaalisen vuorovaikutuksen dialektiikkaan eli niihin eriäviin ääniin, jotka kilpailevat saman kohteen julkisesta kuvauksesta ja tulkinnasta (ks. myös Agha, 2007, s. 383-384; Bakhtin 1981). Tässä artikkelissa selvitetään, millaisilla tekstuaalisilla rakenteilla yritysten verkkosivujen visio-, missio- ja strategiateksteissä hallitaan moniäänisyyttä ja miten äänten välisiä kontrasteja ja suhteita eksplisiittisesti signaloidaan.

Vaikka visio-, missio- ja strategiatekstien tehtävistä ja käyttötavoista on esitetty osittain eriäviäkin mielipiteitä, yleensä katsotaan, että ne on suunnattu laaja-alaiselle yleisölle: yrityksen omalle väelle, asiakkaille, sijoittajille, muulle yhteiskunnalle (ks. esim. Amato \& Amato, 2002; Bartkus, Glassman \& McAfee 2000; Drohan, 1999; Falsey, 1989; Swales \& Rogers, 1995; Virsu, 2012; Williams, 2008). Teksteissä joudutaan siis huomioimaan monenlaisten ihmistyyppien ja yhteisöjen arvot, intressit ja uskomukset. Vastaavasti niillä on katsottu olevan funktionaalisesti monipuolinen luonne. Yhtäältä niillä on yrityksen tuotteita ja palveluita asiakkaille esittelevä ja markkinoiva funktio. Ne voidaan siis sijoittaa osaksi promotionaalista genrekoloniaa (Bha- tia, 2004) eli päämääriltään samankaltaisten, tässä tapauksessa markkinoivien, tekstilajien muodostamaa ryvästä. Ne eivät kuitenkaan ole ominaisuuksiltaan tyypillisimpien promotionaalisten tekstien eli mainosten kaltaisia, vaan sijaitsevat pikemminkin genrekolonian laitamilla kuin keskuksessa. Toisaalta teksteillä on yritysviestintään ja johtamiseen liittyviä funktioita. Niillä viestitään niin sisäisesti kuin ulkoisesti yrityksen pyrkimyksistä, toimintaperiaatteista ja muista sitoumuksista. Niillä hallitaan yrityksen toimintaa muuttuvien olosuhteiden keskellä ankkuroimalla yrityksen identiteettiä ja kantamalla yrityskulttuurin periaatteita kontekstista toiseen. $\mathrm{Ne}$ ovat siis metakulttuurista diskurssia, joka on tarkoitettu historiallisesti jatkuvaksi, kumuloituvaksi, liikkuvaksi ja erilaisissa tilanteissa rekontekstualisoitavaksi. Tässä artikkelissa huomion kohteena on se, miten visio-, missio- ja strategiateksteissä eksplisiittisesti hyödynnetään moniaänisyyttä ja intertekstuaalisuutta eli sitä, miten teksti itsessään mallintaa omaa historiaansa ja suhdettaan toisiin ääniin (ks. Agha, 2007, s. 64-77; Bauman \& Briggs, 1990, s. 75; Irvine, 1996; Urban, 1996, s. 21).

Visio-, missio- ja strategiateksteillä on keskenään merkittäviä funktionaalisia samankaltaisuuksia, mutta myös keskinäinen työnjakonsa. Näiden rakenteeltaan ja tehtäviltään toisilleen läheisten tekstilajien voikin katsoa muodostavan oman genrekoloniansa. (Ks. myös Visakko, 2018 ja siinä mainitut lähteet.) Tutkimuksen aineistona toimivat tekstit ovat siis varsin monimuotoisia: niillä on yhtäältä kullekin tekstilajille tyypillisiä yleisiä piirteitä, jotka samalla heijastavat yritysmaailman yleisiä käytänteitä ja vaatimuksia, toisaalta ne palvelevat kunkin yksittäisen yrityksen erityisiä tarpeita julkaisuhetkellä. Eksistentiaalinen rationaalisuus - yrityksen identiteetin sovittaminen vallitseviin olosuhteisiin - onkin näkökulma, joka yhdistää nämä yleisemmät ja yksityisemmät päämäärät. 


\section{AINEISTO JA METODI}

Tutkimuksen aineisto on koottu vuoden 2007 aikana Suomen Akatemian rahoittamassa Alistus ja konteksti -hankkeessa (2007-2010). Aineisto koostuu 131:stä yritysten verkkosivuilta kerätystä tekstistä, jotka sisältävät visioksi, missioksi tai strategiaksi nimetyn osion tai vastaavassa asemassa esiintyneen esimerkiksi tehtäviksi tai toiminta-ajatuksiksi nimetyn osion. Aineiston kokonaisvirkemäärä on noin 2200 ja sanamäärä noin 19900 . Aineistosta on tässä tutkimuksessa käyty läpi joukko sellaisia leksikaalis-kieliopillisia ja typografisia piirteitä, joita on pidetty moniäänisyyden tai intertekstuaalisuuden tyypillisimpinä signaaleina. Huomion kohteena ovat kuitenkin yksittäisten ilmaustyyppien sijaan ne laajemmat tekstuaaliset rakenteet, joiden osina ilmaukset esiintyvät, eli ilmausten funktiot tekstien kokonaisrakenteessa (ks. esim. Bhatia, 2004, s. 3-26). Yksittäiset ilmaustyypit ovat siis toimineet heuristisina apuvälineinä: niiden avulla on etsitty aineiston teksteille tyypillisiä moniäänisyyden hallintaan liittyviä rakenteita, jotka on sitten jäsennetty kvalitatiivisen diskurssianalyysin keinoin. Analyysiosioissa (3-7) esitellään viisi erilaista tapausryhmää, ja diskussio-osiossa (8) pohditaan vielä, millaisia yleistyksiä niiden pohjalta voi tehdä.

Tekstiartefaktit syntyvät entekstualisoinniksi kutsutun tuotantoprosessin seurauksena (ks. Agha, 2007; Bauman \& Briggs, 1990; Silverstein \& Urban, 1996). Tekstin muoto- ja merkitysrakennetta tuotettaessa tehdään valintoja monenlaisista tarjolla olevista aineksista. Yhtäältä tekstin tuottajat voivat kuvailla kielellisesti omaa kokemusmaailmaansa hyödyntämällä vakiintuneita kulttuurisia resursseja, kuten leksikaalis-kieliopillisia konstruktioita, tekstilajeja, rekistereitä tai diskursseja. Toisaalta he voivat osittain nojata valmiisiin kielellisiin representaatioihin, jo aiemmin muotoiltuihin merkityksiin, kuten omien ja toisten kirjoituksiin ja puheisiin. ${ }^{1}$ Entekstualisointiprosessissa nämä ainekset muotoillaan ja sommitellaan käyttökontekstiinsa sovitetuksi koherentiksi kokonaisuudeksi. Kaikki tekstit ovat näin ollen moniäänisiä kudelmia ympäröivistä semioottisista maailmoista. Niitä voi pitää metadiskursiivisina tulkintoina aiemmista diskursseista ja metarepresentaatioina toisista representaatioista (ks. Shore, 2005; Urban, 1996). Oma kysymyksensä on se, miten tällaiset metadiskursiiviset tai metarepresentatiiviset suhteet tulevat sosiaalisessa vuorovaikutuksessa eri osallistujille tunnistettaviksi. Tarkoitan tässä tutkimuksessa äänellä sellaista tekstistä segmentoitavissa olevaa merkkikokonaisuutta, joka voidaan kontrastiivisesti erottaa ympäröivästä tekstistä ja jolle voidaan antaa jokin sosiaalinen tai kulttuurinen luonnehdinta (esim. minkä yksilön tai millaisen ihmistyypin äänestä on kyse) (ks. Agha, 2005; Bakhtin, 1986). Ääniä voivat olla esimerkiksi sävyn muutos saman puhujan puheessa (kontrasti semioottisten rekisterien välillä) tai sitaatti toisen puheesta osana omaa puhetta (kontrasti puhujien ja diskursiivisten roolien välillä). Tekstit voivat sisältää vaihtelevassa määrin sellaisia metadiskursiivisia signaaleja, jotka selittävät entekstualisoitujen ainesten keskinäisiä suhteita ja merkitsevät ne eksplisiittisesti erillisiksi ääniksi tekstin kokonaisrakenteessa.

Ne tekstuaaliset rakenteet, jotka tässä tutkimuksessa on valikoitu systemaattisen tarkastelun kohteeksi, sisältävät jonkin kielellisin merkein eksplikoidun, intertekstuaalista suhdetta ilmaisevan metadiskursiivisen kehystyksen

1 Usein tekstejä tuotetaan ja tulkitaan yhteisöissä erilaisissa vakiintuneissa sosiaalisissa ketjuissa tai verkostoissa, joissa kielenainesta välitetään, kierrätetään ja muokataan eri tavoin vaiheesta toiseen ja joissa eri vaiheilla ja niihin liittyvillä tekstilajeilla on oma tehtävänsä osana diskursiivisen työnjaon kokonaisuutta (ks. esim. Bhatia, 2004; Fairclough, 1992; Solin, 2004). 
(ks. Taulukko 1). ${ }^{2}$ Näissä tapauksissa jokin kielenaines on siis havaittavasti toiseutettu tekstin pinnassa tavalla, joka ohjaa tulkitsemaan sen eri lähteestä peräisin olevaksi ääneksi - riippumatta siitä kuinka tunnistettava lähde tällä äänellä on. Faircloughin (1992, s. 117-123) mukaan tällainen avoin intertekstuaalisuus voi yhtäältä ilmetä erilaisina vakiintuneina referoinnin - puheen tai ajattelun representoinnin (eli metarepresentaation) - kieliopillisina keinoina, kuten suorana tai epäsuorana esityksenä (ks. myös Shore, 2005). ${ }^{3}$ Suomen kielessä tällaisiin ilmaustyyppeihin kuuluvat erityisesti johtolauseen ja että-lauseen tai referatiivirakenteen yhdistelmät sekä mukaan- ja mielestä-postpositioiden muodostamat lausekkeet (ks. esim. Kalliokoski, 2005; ISK § 1476-1480). Toisaalta Faircloughin (1992, s. 117-123) mukaan avoin intertekstuaalisuus

2 Toisin sanoen tarkasteltavissa tapauksissa kehystyksellä itsellään on tekstissä oma hahmonsa. Se on joko propositionaalisesti eksplisiittinen ("Hän sanoi, että") tai perustuu vakiintuneeseen kielelliseen merkistöön (esim. lainausmerkkeihin). Tietenkin myös esimerkiksi kulttuurisesti vakiintuneisiin, laajalti tunnistettuihin rekistereihin perustuvat äänten väliset rajat ovat oikeiden tulkintamallien valossa hyvin selkeitä ja näkyviä eli siinä mielessä "eksplisiittisiä". Eksplisiittisyys itsessään onkin melko epämääräinen käsite. Ennemmin voisi puhua esimerkiksi emblemaattisuuden eri muodoista ja asteista eli siitä, kuinka selkeästi tulkittavia erilaiset merkit ovat ja millä tavalla (ks. Kockelman, 2013, s. 74-79; Visakko 2015, s. 194-199). Samoin aivan spesifisiinkin toisiin teksteihin on periaatteessa mahdollista viitata ilman mitään kehystystä, jos vastaanottajan voi olettaa tunnistavan viittauksen.

3 Intertekstuaalisuutta on jaoteltu perustavaan ja avoimeen intertekstuaalisuuteen (Fairclough, 1992; suomenkieliset nimitykset Heikkiseltä, 2000, s. 74). Perustavalla intertekstuaalisuudella, josta joskus käytetään myös nimitystä interdiskursiivisuus, on tarkoitettu suurin piirtein samaa kuin moniäänisyydellä edellä eli sitä, että kielenkäytössä nojataan monin eri tavoin aiempaan kielenkäyttöön, erityisesti erilaisiin vakiintuneisiin kulttuurisiin malleihin, kuten tekstilajeihin, rekistereihin tai diskursseihin (eli käsitteistämisen tapoihin). Perustavaa intertekstuaalisuutta tai interdiskursiivisuutta on siis esimerkiksi se, että aineiston visio-, missio- ja strategiateksteillä on monia samankaltaisia tekstilajikohtaisia rakenteellisia ja vuorovaikutuksellisia piirteitä, vaikka niillä tai niiden tuottajilla ei ole mitään suoraa kytköstä toisiinsa. voi ilmetä lauseen sisältämänä presuppositiona eli välttämättömänä taustaoletuksena. Esimerkiksi kieltolauseet ovat pragmaattisesti tunnusmerkkisiä ja presupponoivassa suhteessa vastaavan myöntölauseeseen (ks. myös ISK $\S 1616$; Lyons, 1977, s. 768-777; Larjavaara 2007, s. 274-275). Kieltolause implikoi, että kielletty asiaintila olisi jollakin tavalla kontekstissa odotuksenmukainen, ja usein väitteen kieltäminen onkin reaktio johonkin toiseen ääneen, joka on sitoutunut kyseiseen väitteeseen. Kysymyslauseet (mukaan lukien jotkin ns. retoriset kysymykset) puolestaan esittävät jonkin tilanteessa relevantin proposition jollekin tilanteen osallistujista oletetusti epäselvänä ja projisoivat intertekstuaalista suhdetta mahdollisiin vastauksiin. Lisäksi Fairclough (1992, s. 117-123) lukee avoimeen intertekstuaalisuuteen varausten kaltaiset metadiskursiiviset signaalit, joilla tekstin tuottaja voi erottaa omasta tekstistään erilaisia sitoutumisen tasoja. Aineistossa esiintyvien varausten tapauksessa on kuitenkin usein vaikea väittää, että ne välttämättä edellyttäisivät taustakseen jotakin toista ääntä. ${ }^{4}$ Siksi niitä ei ole systemaattisesti käyty läpi aineistosta. Sen sijaan tarkasteltaviin piirteisiin on laskettu lainausmerkit kaikissa käyttötavoissaan. Samoin analyyseissa on huomioitu samankaltaisissa tehtävissä esiintyvät typografiset keinot, kuten lihavoinnit, sekä

4 Implisiittisemmin toki jokainen julkilausuttu propositio asettuu sosiaalisessa vuorovaikutuksessa aina dialogiseen suhteeseen niin puhujan omiin kuin toisten edeltäviin tai ennakoituihin lausumiin samoin kuin niitä perusteleviin (tai vastustaviin) syihin ja niitä tukevaan (tai kumoavaan) havaittavaan evidenssiin. Propositionaalisen semioosin voi ylipäänsä nähdä jäsentyvän verkostomaisesti indeksikaalis-inferentiaalisten päättelysääntöjen varaan (ks. Brandom, 2000; Kockelman, 2004, 2006), jolloin päätelmät siitä, mitä muuta olisi voitu tai on pitänyt sanoa, ovat aina läsnä. Tässä artikkelissa on kuitenkin keskitytty eksplisiittisesti merkittyihin ja prototyyppisimpiin tapauksiin. Tarkasteltavien piirteiden listasta on rajattu pois myös sellaisia ilmaustyyppejä, joista on vain pari esiintymää (esim. kielteiset $m$ AttArakenteet). Myöskään esimerkiksi yksittäisiä presupposition sisältäviä leksikaalisia predikaatteja (esim. epäillä, kieltää, lakata jne.) ei ole haettu aineistosta erikseen. 
Taulukko 1. Tutkittujen piirteiden lukumäärät aineistossa.

\begin{tabular}{|ll|l|}
\hline \multicolumn{2}{|l|}{ Piirre } & Tapauksia \\
\hline 1. & Lainausmerkit & 26 \\
\hline 2. & Puhetta tai ajatusta esittävä että-lause tai referatiivirakenne & 68 \\
\hline 3. $\quad$ mukaan- tai mielestä -postpositiolauseke & 11 \\
\hline 4. $\quad$ Kysymyslause & 9 \\
\hline 5. $\quad$ Kieltolause & 63 \\
\hline & Yhteensä & 177 \\
\hline
\end{tabular}

koodinvaihdot suomesta englantiin, jotka lainausmerkkien tavoin näkyvästi rajaavat jonkin kielenaineksen ympäristöstään.

Alkuperäinen - tai sellaisena esitetty - aines voi näkyä entekstualisoidusta muodosta vaihtelevassa määrin. Voidaan puhua esimerkiksi replikaatiosta ja responssista (Urban, 1996, s. 22-23). Replikaatiossa alkuperäinen kielenaines pyritään jäljentämään mahdollisimman tarkasti uuteen kontekstiin. Responssissa taas johonkin edeltävään diskursiiviseen ainekseen on kopioinnin sijaan reagoitu tai vastattu suoremmin, jolloin alkuperäinen aines ei välttämättä näy tekstissä kuin implisiittisesti. Edeltävää diskursiivista ainesta voidaan mm. kommentoida, kehitellä edelleen, parodioida tai kumota (ks. myös Bakhtin, 1986; Eisenlohr, 2010, s. 326).5 Osa seuraavaksi tarkastelluista ilmaustyypeistä merkitsee eksplisiittisesti jonkin kielenaineksen toisesta lähteestä kopioiduksi (1) tai muulla tavoin välitetyksi ääneksi

5 Diskursiivisten aineisten välitysprosessien muotoutumiseen vaikuttavat esimerkiksi alkuperäisen lähteen ja tekstin tuottajan väliset sosiaaliset suhteet sekä itse prosessia sääntelevät kulttuuriset normit (genrekohtaiset viittauskonventiot, tekijänoikeuslait yms.) (ks. esim. Urban, 1996). Intertekstuaaliset suhteet voikin nähdä myös valtasuhteina ja sosiaalisena kontrollina: diskurssien välityksestä päättävät tahot voivat valinnoillaan vaikuttaa siihen, millaiset äänet leviävät ja pääsevät kuuluviin jossakin yhteisössä ja millaiset eivät (ks. esim. Briggs \& Bauman, 1992; Fairclough, 1992; Lemke, 1995). Voidaan puhua esimerkiksi valtaannuttavista ja hiljentävistä käytänteistä (ks. esim. Solin 2012, s. 559). Intertekstuaalisiin suhteisiin liittyviä valta-asetelmia voidaan nähdä niin instituutioiden tai yritysten sisällä kuin instituutioiden tai yritysten välillä (ks. Solin 2006, s. 85).
(2-3). Toiset (4-5) pikemminkin aktivoivat erilaisia oletettuja, ennakoituja tai kulttuurisesti vallitsevia ääniä, joita teksteissä voidaan näiden keinojen avulla nostaa käsiteltäväksi. Seuraavissa analyysiosioissa hahmottelen viisi erilaista tapausryhmää, joiden alle suurin osa ilmaustyyppien esiintymistä verrattain luontevasti asettuu.

\section{ONGELMAT, AUKTORITEETIT JA EMPATIA}

Aineiston visio-, missio- ja strategiateksteille tyypillistä tekstuaalista ja vuorovaikutuksellista rakennetta on mahdollista kuvata eräiden kulttuurisesti vakiintuneiden kausaalis-evaluatiivisten diskurssikuvioiden avulla (ks. Hoey, 1983, 2001). Tekstien perusrakennetta voidaan kuvata PÄ̈̈MÄÄR Ä-KEINO-tyyppisellä diskurssikuviolla, johon monissa teksteissä yhdistyy lisäksi ONGELMA-RATKAISU-tyyppinen kuvio. ${ }^{6}$ Teksteissä toisin sanoen pro-

6 Hoeyn mallissa PÄÄMÄÄR Ä-KEINO ja ONGELMARATKAISU kuuluvat samaan diskurssikuvioiden perheeseen, jota yhdistää sama skemaattinen rakenne. Kussakin diskurssikuviossa esitellään tilanne, joka vaatii joltakin tekstin kuvaamista osallistujista sopivaa reaktiota (esimerkiksi päämäärän saavuttamista tai ongelman ratkaisemista jonkin keinon avulla). Alku- ja lopputilanteen välille hahmottuu kuvioissa kausaalinen suhde: toimijan intentionaalinen reaktio vallitseviin olosuhteisiin johtaa uudenlaisiin olosuhteisiin (ks. Hoey 2001, s. 177). Kausaalisuus taas kytkeytyy evaluaatioon: reaktiota vaativa tilanne on kuvioissa jollakin tavalla epäsuotuisa tai vähintäänkin reaktion puute olisi epätoivottavaa, kun taas reaktion aikaansaama lopullinen asiaintila on myönteinen. 
totyyppisesti kuvaillaan 1) jokin päämäärä, johon yritys sitoutuu, 2) päämäärän saavuttamisen mahdollistava keino ja/tai 3) toiminnan myönteiset lopputulokset. Päämäärä- ja ongelmakuvioiden yhdistelmässä yrityksen päämääräksi hahmottuu nimenomaan jonkin asiakkaan toimintaa uhkaavan ongelman ratkaiseminen tai ehkäiseminen. Tällaiset kuvioyhdistelmät siis sommittelevat niin yrityksen kuin asiakkaan pyrkimykset ja intressit osaksi koherenttia kausaalis-evaluatiivista verkostoa (ks. Visakko, 2018).

Ongelmanratkaisukuvion aktivoinnissa keskeinen rooli on mm. kielto- ja ehtolauseilla sekä erilaisilla leksikaalisilla valinnoilla, joilla implisiittisesti viitataan asiakkaan toimintaa koskevaan uhkakuvaan tai vastavoimaan. Esimerkissä (1) auttaa-verbin argumenttirakenne projisoi yrityksen ja asiakkaan välille asymmetrista suhdetta, jossa yritys hahmottuu asiakkaan toiminnan kannalta tarpeelliseksi apua antavaksi agentiksi ja asiakas apua tarvitsevaksi patientiksi (ks. myös Hoey, 1983, s. 86; 2001, s. 129). Ongelmaa rakennetaan esimerkissä myös kielto- ja ehtorakenteella, jossa epätoivottava tilanne ("oikeiden roolipelaajien löytäminen ei ole mahdollista") ei toteudu sillä ehdolla, että yritys saa toteuttaa päämääräänsä.

(1) Missiomme on auttaa sinua kokoamaan huippujoukkue, jossa on tämän ajan haasteiden vaatimaa monipuolista osaamista. - - Oikeiden roolipelaajien löytäminen ei olisi mahdollista, ellei Henkilöstöliiga tekisi omaa osuuttaan poikkeuksellisen perusteellisesti.

Samalla tavalla myöhemmässä esimerkissä (2) ongelmaa implikoi yrityksen toiminnan myönteisiä seurauksia kuvaavaan lauseeseen (Näin kiinteistöliiketoiminnan jobtaminen ei ole enää arvailua) liittyvä presuppositio ("johtaminen on [ollut] arvailua"). Itse ongel- maa ei siis yleensä kuvailla yksityiskohtaisesti (vrt. replikaatio), vaan se esiintyy implisiittisenä äänenä, johon tekstissä vastataan (vrt. responssi) korostamalla yrityksen ongelmanratkaisijan roolia. ${ }^{7}$

Seuraavissa esimerkeissä jokin osa ongelmakuviosta on ilmaistu yrityksen toimitusjohtajan äänellä joko vapaana tai johtolauseellisena suorana esityksenä. Esimerkissä (2) toimitusjohtaja esittelee ensin yleistetyn, globaalin ilmiön hyödyntäen nominaalistettuja kuvauksia (sopeutuminen ilmastonmuutokseen ja sen pysäyttäminen) ja avoimia viittauksia ([Ø:n] on otettava vakavasti). Tämän jälkeen hän johtaa ilmiöstä tarkemmin rajatun, nimenomaan asiakasyrityksiä koskettavan ajankohtaisen haasteen, jonka välittömäksi ratkaisuksi yrityksen tuotetta tarjotaan (työkalut ovat jo valmiina; on otettava vakavasti jo $n y t)$.

\section{(2) Ilmastonmuutos haastaa}

\section{kiinteistönpidon kehittymään}

"Sopeutuminen ilmastonmuutokseen ja sen pysäyttäminen on yksi lähivuosien megatrendeistä, joka on otettava vakavasti jo nyt, sanoo Fatman Oy:n toimitusjohtaja Kari Hein ja muistuttaa, että työkalut ovat jo valmiina." [sic] Origon [= yrityksen tarjoaman objelmiston] toiminnot mahdollistavat yrityksen laatujärjestelmän mukaisen aikataulutetun ja ennaltaehkäisevän kiinteistönpidon, jossa taktiset päätökset pohjautuvat valittuun strategiaan ja oikeisiin resursseihin. Origon voima syntyy siitä, että kaikki informaatio on aina ajan tasalla ja kaikkien käytettävissä. Näin kiinteis-

\footnotetext{
7 Ongelman implikointia selittänee ainakin se, että markkinointikontekstissa potentiaalisen asiakkaan puutteiden osoittelu ei välttämättä olisi viestinnällisesti viisasta. Huomio on turvallisempaa kohdistaa yrityksen ongelmanratkaisijan rooliin. (Ks. myös Lozachmeur, 2007, s. 131; Kuikka, 2009, s. 47.)
} 
töliiketoiminnan johtaminen ei ole enää arvailua.

Toimitusjohtajan ääni esiintyy siis yhtäältä yrityksen henkilöitymänä toimivana inhimillisenä auktoriteettina sekä toisaalta lukijoita varoittavana ja velvoittavana asiantuntija-auktoriteettina. Ongelma esitetään yleistettynä ja yhteisenä: se spesifi asiakkaiden ongelma, jota yritys tuotteineen ratkoo, on osa globaalia ongelmaa, joka koskee kaikkia. Ongelman kuvailu voi olla sitä yksityiskohtaisempaa, mitä yleisempänä se esitetään.

Esimerkissä (3) toimitusjohtaja sen sijaan näyttäytyy ennemminkin empaattisena hahmona, joka pyrkii lieventämään kuvatun tilanteen ongelmallisuutta asiakkaan näkökulmasta ${ }^{8}$. Edellisen esimerkin tavoin ongelmaa kuvaillaan yleistetysti kaikkia yrityksiä koskevana (Digitaalisen tiedon määrä yrityksissä kasvaa nopeasti. Organisaatiot etsivät uusia keinoja hallita ja jakaa sisältöä- -), mutta tässä toimitusjohtaja muotoilee ongelmanratkaisun korostetusti juuri edustamansa yrityksen tehtäväksi (Uskomme Profiumissa semanttisten teknologioiden auttavan meitä kohtaamaan tämän haasteen. - - Automatisoimalla prosesseja ja nopeuttamalla tiedonvälitystä tuomme asiakkaillemme merkittäviä kustannussä̈̈stöjä). Toimitusjohtajan puheenvuoro toisin sanoen asemoi yrityksen samalle puolelle asiakkaan kanssa niin, että yritys ottaa asiakkaan(kin) haasteen kannettavakseen.

\section{(3) Missiomme}

Digitaalisen tiedon määrä yrityksissä kasvaa nopeasti. Organisaatiot etsivät uusia keinoja hallita ja jakaa sisältöä, joka voi olla tekstiä, grafiikkaa, kuvia, videota ja muuta digitaalista dataa. "Uskomme

8 Äänen lähde on tässä identifioitavissa toimitusjohtajaksi tekstin vieressä sijaitsevan kuvan ja kuvatekstin perusteella.
Profiumissa semanttisten teknologioiden auttavan meitä kohtaamaan tämän haasteen. Hyödyntämällä metadataa ja uusimpia teknologioita voimme vaikuttaa monimuotoisen tiedon jakelu- ja hakuprosesseihin. Automatisoimalla prosesseja ja nopeuttamalla tiedonvälitystä tuomme asiakkaillemme merkittäviä kustannussäästöjä."

Kahdelle edelliselle esimerkille on yhteistä se, että tekstistä erottuu yksilöidyn henkilön referoitu ääni yrityksen institutionaalisen äänen vastapainoksi. Molemmissa tapauksissa referointi liittyy tekstiin, jossa käsitellään oletettuja ongelmia. Voikin ajatella, että kyseessä on kaksi erilaista tapaa lieventää ongelmakuvioon liittyviä viestinnällisiä riskejä sekä säädellä sitä sosiaalista suhdetta, jota teksti välittää. Ensimmäisessä esimerkissä painottuu toimitusjohtajan yhteiskunnallinen auktoriteettirooli ja asiakkaan oma rooli ongelman ratkaisussa yrityksen tarjoaman tuotteen avulla, jälkimmäisessä taas toimitusjohtajan empaattinen rooli ja yrityksen rooli asiakkaan ongelman ratkaisussa. Kummassakin korostetaan eri tavoin eksplisiittisen moniäänisyyden avulla yrityksen roolia ongelmanratkaisijana. ${ }^{9}$

\section{INSTITUTIONAALISESTA HENKILÖKOHTAISEEN}

Tässä osiossa käsiteltävissä tapauksissa yrityksen oman äänen eri tasojen välille hahmottuu kontrasti, jota voidaan luonnehtia esimerkiksi siirtymäksi institutionaalisemmasta henkilökohtaisempaan näkökulmaan. Esimerkit (4) ja (5) koostuvat kumpikin kehystävästä joh-

9 Satunnaisesti aineiston teksteissä saatetaan viitata myös ulkopuolisiin auktoriteetteihin, kuten tutkimuksiin tai säädöksiin. Tällöinkin viittaukset ovat yleensä varsin yleistettyjä (Monien tutkimusten ja selvitysten mukaan Suomen ja Uudenmaan kansainvälinen kilpailukyky on hyvä). 
toilmauksesta, joka sisältää kommunikatiivista toimintaa kuvaavan verbin (todeta, luvata) sekä tämän toiminnan sisältöä kuvaavan ettälauseen. Lisäksi kumpikin esimerkki sisältää affektia (tunnetilaa) tai intentiota (pyrkimystä) kuvaavan aineksen (on ilo, uskallam$m e$ ). Ne siis projisoivat lausujakseen sellaista oliota, jossa voi vallita ilon tai uskalluksen kaltaisia tiloja ja joka kykenee refleksiivisesti kielentämään omia tilojaan. Huomionarvoista on, että kummassakaan esimerkissä ei ole substantiivilausekkeena (NP) ilmipantua subjektia. Jälkimmäisessä esimerkissä monikon 1. persoonan persoonataivutus viittaa yritykseen yksilöistä koostuvana yhteisöllisenä entiteettinä. Ensimmäisessä esimerkissä sen sijaan ilon kokija ja toteaja edustuu nollana, jonka voi ajatella viittaavan personifioivasti koko yritykseen kokonaisuutena (vrt. "yhtiöllä on ilo todeta") tai yleistettyyn yrityksen edustajaan (vrt. "minulla/meillä on ilo todeta").

(4) On ilo todeta, että nämä tavoitteet yhtiö on saavuttanut kaikkina neljänä toimintavuotenaan.

(5) Ja uskallamme luvata myös sen, että löydät kauttamme nopeasti juuri sinun pelityyliisi sopivat tehokentälliset.

Esimerkit kääntävät eri tavoin yrityksestä esiin subjektimaisen puolen, jolla on affektisintentionaalisia tiloja ja niiden motivoimia kielellisesti ilmaistuja sitoumuksia. Lisäksi esimerkeissä korostuu performatiivisuus: niissä eksplikoidaan, minkälaisesta kielellisestä toiminnasta ja julkisesta sitoumuksesta on kyse (todeta, luvata). Teksti siis kommentoi välittämäänsä sosiaalista toimintaa ja sen emotionaalista sävyä, mikä kasvattaa vaikutelmaa yrityksestä kokevan, tietoisen olennon kaltaisena. Tällaiseen olioon lukijayksilönkin on kenties helpompi samaistua henkilökohtaisesti.

Esimerkki (6) puolestaan alkaa otsikolla ja lainausmerkkeihin sijoitetulla itsenäisellä NP:llä, jonka lähteeksi ei ole ilmoitettu mitään henkilöä tai toista tekstiä. Tällaiset tapaukset muistuttavat ulkoisesti johtolauseetonta vapaata suoraa esitystä, mutta eivät prototyyppisen vapaan suoran esityksen tavoin sisällä tulkintaohjetta, jonka perusteella äänen lähde voitaisiin riittävällä varmuudella päätellä (vrt. Kalliokoski, 2005; ISK \$1463). Lainausmerkein erotettu lauseke näyttää toimivan tekstissä ingressin tapaisena kiteytyksenä ja asettuvan parafraasin kaltaiseen suhteeseen leipätekstin ensimmäisen virkkeen kanssa niiden yhteisen kehystyksen (otsikko) ja toistuvan muotoaineksen (sisältö-) perusteella. Ne siis ilmaisevat ikään kuin saman asian, yrityksen toiminta-ajatuksen, kahdesta erilaisesta näkökulmasta muotoiltuna.

\section{(6) Toiminta-ajatus}

"Sisältöä unelmiin ja elämän tarpeisiin." A-lehdet tuottaa asiakkaille ja lukijoille korkeatasoisia sisältökokonaisuuksia painetun ja sähköisen median keinoin, jotka ympäristönä palvelevat myös muiden yritysten markkinoinnin ja viestinnän tarpeita.

Leipätekstissä sisältö-lekseemin sisältävä lauseke sijaitsee objektina lauseessa, joka eksplikoi, että kyseinen NP kuvaa tietynlaista tuotetta (A-lehdet tuottaa). Sen sijaan lainausmerkein erotetussa kiteytyksessä jää pääteltäväksi, miten sisältö liittyy muuhun tekstiin. Se on siis väljemmin integroitu, sloganin kaltainen osanen.

Lausekkeiden muotoiluissa on selkeitä kontrasteja. Lainausmerkein erotetun NP:n edussanana toimii yleiskielinen sisältö, kun taas leipätekstissä käytetään muodollisempaa, erikois- tai ammattikieleen kuuluvaa ilmausta sisältökokonaisuus. Lainausmerkein erotetussa NP:ssä on eksplikoitu tuotteen tarjoamisen tarkoitus yleisinhimillisestä ja 
yksilökeskeisestä näkökulmasta (unelmiin ja elämän tarpeisiin). Leipätekstin adverbiaalit sen sijaan korostavat konkreettista keinoa ja teknistä toteutusta. Lisäksi hyötyjät on nimetty tarkasti (asiakkaille ja lukijoille). Lainausmerkein erotetussa lausekkeessa hyötyjää ei ole eksplikoitu. Voi ajatella, että kyseessä on genetiivimärittteen tai vastaanottajaa ilmaisevan adverbiaalin nollaedustus (Sisältö̈ä [ø:n]/ [ø:lle] unelmiin ja elämän tarpeisiin), mikä mahdollistaa yleistävän ja avoimen tulkinnan, joka kutsuu lukijaa asettumaan hyötyjän rooliin (vrt. Laitinen, 1995; ISK \$1347-1365; Mäntynen, 2003, s. 156).

Siirtymä irrallisesta NP:stä leipätekstiin muuttaa siis tekstin näkökulmaa. Muotoilut kuvaavat saman kohteen kahden erilaisen kulttuurisen epistemologian tai tietokehyksen valossa, joista kumpikin ohjaa huomion erilaisiin havaintoihin ja toimintamahdollisuuksiin ja samalla rakentaa osittain erilaista sosiaalista suhdetta lukijoihin (ks. esim. Kockelman, 2013, s. 168-169; myös Holleman \& Pander Maat, 2009). Ensimmäinen lähestyy kohdetta yksilöllisten ideaalien ja tarpeiden kautta ja rakentaa henkilökohtaisempaa suhdetta lukijaan, mikä on tyypillistä esimerkiksi mainosdiskursseille. ${ }^{10} \mathrm{Jälkim-}$ mäinen liikkuu yritystalouden maailmassa ja osoittaa viestinsä lukijalle muodollisemmin. Kahden muotoilun parafrastisella paralleelilla näiden eri maailmojen - inhimillisten unelmien ja tarpeiden sekä liiketalouden - välille luodaan assosiatiivisia sidoksia, joilla voidaan myös ohjata lukijan mielikuvia.

Lainausmerkeillä voidaan varsinaisen siteeraamisen lisäksi esimerkiksi ironisoida kielenainesta, ottaa siihen etäisyyttä tai arvioida

10 Tällainen institutionaalisen ja henkilökohtaisen sekoittuminen voikin heijastaa juuri tekstien hybridiluonnetta: tekstit ovat sekä strategisen johtamisen että markkinoinnin apuvälineitä ja sijaitsevat promotionaalisten ja yritystalousdiskurssien leikkauspisteessä (ks. Bhatia, 2008). kielenaineksen sopivuutta käyttöyhteyteensä. Kaikissa näissä käytöissä lainausmerkeillä on metadiskursiivinen tehtävä: niillä rajataan tietty kielenaines ympäröivästä tekstistä erilliseksi kokonaisuudeksi ja osoitetaan tekstin tuottajan sitoutumisen astetta ja asennetta tätä kielenainesta kohtaan. Myös esimerkissä (6) lainausmerkit herättävät kysymyksen kielenaineksen lähteestä ja asemasta tekstissä. Osittain lainausmerkit voivat selittyä kiteytyksen ingressinomaisella asemalla: kiteytyksen voi ajatella referoivan ja tiivistävän leipätekstiä tietystä näkökulmasta. Kiteytyksellä ja leipätekstillä olisi siis esimerkkien (4) ja (5) tapaan sama lähde. Toisaalta voi ajatella, että lainausmerkit luovat vaikutelman jonkun yleistetyn ja identifioimattoman henkilön puheen tai ajatusten referoinnista (vrt. toimintaajatus) (ks. Shore, 2005, s. 78). Yhdessä nollapersoonan kanssa lainausmerkit rakentaisivat siis tekstiin eräänlaisen jaetun inhimillisen kokemuksen äänen. Edelleen lainausmerkit kiinnittävät huomiota nimenomaan ilmauksen muotoon (vrt. esim. 7). Lainausmerkkeihin sijoitetussa NP:ssä korostuu ytimekäs, sloganin kaltainen muoto, joka yleiskielisenä, helposti muistettavana ja tekstiyhteydestä irrotettavana soveltuu siirrettäväksi monenlaisiin konteksteihin. Tekstin rakenteen voi siis ajatella tässä edistävän diskursiivisen aineksen kopiointia ja rekontekstualisointia nostamalla tarjolle tietyn puhemallin.

\section{HAITALLISTEN ÄÄNTEN HALLINTA}

Markkinoiville ja idealisoiville tekstilajeille tyypilliseen tapaan visio-, missio- ja strategiateksteissä yleensä keskitytään käsiteltävien aiheiden myönteisiin puoliin yrityksen näkökulmasta (vrt. esim. 2 ja 3). Niissä voidaan kuitenkin avoimesti nostaa kumottavaksi tai kommentoitavaksi myös yrityksen kannalta epätoivottavia mielipiteitä, uskomuksia tai 
ennakkoluuloja. Esimerkiksi katkelmassa (7) leluja ja muita lastentarvikkeita valmistavan yrityksen missioteksti nostaa esiin väittämän, jonka mukaan lasten saaminen rajoittaa vanhempien elämää ja tekee siitä värittömämpää. Vaikka väittämä ei suoraan kohdistu yrityksen tuotteisiin, vanhemmuuteen liittyvät uskomukset heijastuvat yrityksen kauppaamien tuotteiden imagoon ja ovat siis osa samaa mielikuvien verkostoa. Väittämää joka tapauksessa käsitellään tekstissä siinä määrin relevanttina yrityksen päämäärien kannalta, että se nostetaan yksityiskohtaisen kriittisen dialogin kohteeksi.

\section{(7) Missiomme}

Luoda tuotteita aktiivisille nykyajan vanhemmille, jotka haluavat lapsilleen parasta

Riippumattomuuden julistus:

On heitä, jotka väittävät, että ulkona syöminen loppuu kun saa lapsia.

Ettei sinulla ole enää koskaan aikaa lukea. Ettet voi enää matkustella.

Ettet enää koskaan tanssi pöydillä... ...Mutta meillä BRIOlla yhtenä tavoitteena on tehdä elämästä helpompaa, rennompaa ja iloisempaa.

Väittämän lähteeksi esitetään monikon 3 . persoonan pronominilla jokin epämääräinen joukko ihmisiä (On heitä, jotka väittävät, että- -). Epäsuoran esityksen johtoilmauksen väittää-verbi jo itsessään evaluoi esitettyä propositiota: tekstin tuottaja ei ainakaan lähtökohtaisesti sitoudu sen totuudenmukaisuuteen. Itse väittämä esitetään neljän peräkkäisen että-lauseen listana. Tämän jälkeen seuraava mutta-lause (Mutta meillä BRIOlla - -) rakentaa kontrastin esitetyn uhkakuvan ja yrityksen pyrkimysten välille. Yritykseen viittaava monikon 1. persoonan ilmaus (Meillä) korostaa kontrastia väitteen lähteeseen ("he") nähden - ja näiden väliin asettuu yksikön 2. persoonassa puhuteltu lukija (sinulla). Yrityksen pyrkimyksen kuvauksessa käytetyt positiivisesti evaluoivat komparatiivimuodot (belpompi, rennompi, iloisempi) puolestaan asettuvat semanttiseen oppositioon väittämän eri osiin nähden. Vaikkei tekstissä suoranaisesti väitetä, etteikö alkuperäinen väittämä voisi joissakin tapauksissa pitää paikkaansa, sen rinnalle nostetaan kilpaileva vaihtoehto, jonka yritys väittää mahdollistavansa.

Huomionarvoista on myös, että jakso erottuu selvästi ympäröivästä tekstistä poeettisena performanssina (ks. Bauman \& Briggs, 1990, s. 73-74). Haitallisen väittämän esittelevä ja sitä käsittelevä jakso on eksplisiittisestikin kehystetty julistukseksi. Jakso on strukturoitu toiston varaan: siinä toistuu neljä kertaa että-lause (morfosyntaktisena ja semanttisena yksikkönä) ja ett-alkuinen äänneaines (fonologis-grafeemisena yksikkönä). Kolme viimeistä että-lausetta on lisäksi merkitty itsenäisiksi virkkeiksi, millä voidaan kirjoitetussa tekstissä korostaa ja rytmittää toistoa. Toiston jälkeen, kahden viimeisen virkkeen välillä, on puolestaan käytetty välimerkkejä (kolmea pistettä) odotuksen tai dramaattisen tauon vaikutelman luomiseen.

Esimerkissä (7) eksistentiaalinen rationaalisuus, moniäänisyyden hallinta ja esteettinen tyyli kytkeytyvät toisiinsa. Tekstissä nostetaan esiin saman kohteen julkisesta kuvauksesta kilpailevia ääniä. Potentiaalisesti haitalliset väitteet integroidaan hallitusti tekstuaaliseen ja poeettiseen rakenteeseen, joka neutralisoi ne tai suhteuttaa ne koherentisti yrityksen intresseihin ja pyrkimyksiin. Haitallisuus on toki aina suhteellista. Edellisessä esimerkissäkin yrityksen tuotteet esitetään positiivisessa valossa nimenomaan tarkkaan valikoidun negatiivisen äänen avulla, julistuksenomaisena vastalauseena sen propagoimaan ongelmaan. Viime kädessä haitallisetkin äänet pyritään siis kääntämään yrityksen eduksi. 


\section{METALINGVISTINEN REFLEKTIO JA LUKIJAN REAKTIOIDEN ENNAKOIMINEN}

Tässä osiossa huomio kohdistuu tekstien metalingvistisiin piirteisiin eli siihen, miten niissä käsitellään eksplisiittisesti tekstin välittämiä merkityksiä. Metalingvistisellä reflektiolla voidaan säännellä tekstin synnyttämiä tulkintoja esimerkiksi määrittelemällä käytettyjä ilmauksia, tarkentamalla tulkintaa ohjaavia olettamuksia sekä ennakoimalla eitoivottuja reaktioita. Seuraavissa esimerkeissä ei kuitenkaan ole eksplikoitu yksittäisiä haitallisia ääniä samalla tavalla kuin edellisen ryhmän tapauksissa, vaan kyse on tekstin tulkintaprosessin hallinnasta.

Kaksi ensimmäistä esimerkkiä (8) ja (9) edustavat kysymysmuotoista metalingvistisista reflektiota. Kumpikin sisältää kysymyslauseen, jonka funktiona ei ole vastauksen hakeminen vuorovaikutuksen toiselta osapuolelta vaan pikemminkin omien väitteiden esittäminen tai pohjustaminen itse esitetyllä kysymyksellä. Tällaisten kysymysten avulla tekstissä voidaan simuloida lukijan ääntä ja konstruoida dialogia, jossa vastataan ennakoituihin kysymyksiin (ks. myös Van De Mieroop, 2008, s. 505; ISK \$1705). Kysymyksillä voidaan kommentoida lukijan oletettuja odotuksia ja nostaa mahdollisia ongelmia käsiteltäviksi. Kysymyksillä siis sekä varaudutaan lukijoiden reaktioihin että ilmennetään yrityksen orientaatiota asiakkaan tulkintoihin ja intresseihin.

Esimerkin (8) väliotsikko ennakoi kysymyksen, joka on muotoiltu yleistetyn asiakasyritysten näkökulmasta - eräänlaisena vapaana epäsuorana esityksenä (Mitä hyötyä yritykselle on PYR:stä?). Leipätekstin ensimmäinen virke (meiltä kysytään silloin tällöin, mitä hyötyä - -) referoi saman kysymyksen tarkentaen ja osoittaa samalla, että yleistyk- sen taustalla on joukko toistuvia todellisia kysymyksiä. Kysymyksen eksplikoiminen on kuitenkin sikäli riskialtista, että se aktivoi myös negatiiviset vastausvaihtoehdot ("ei mitään”). Ylipäänsä kysymyksen kysyminen on prototyyppisesti merkki juuri siitä, että sen sisältämän proposition totuusarvo ei ole ilmeinen. Haitallisten tulkintojen ehkäisemiseksi kysymys on integroitu tiiviisti KYSYMYSVASTAUS-rakenteeseen ja siihen lomittuvaan ONGELMA-RATKAISU-rakenteeseen, jotka osoittavat hyödyn yksityiskohtaisesti.

\section{(8) Mitä hyötyä yritykselle}

on PYR:stä [= Pakkausalan

Ympäristörekisteri PYR Oy]?

Edelleenkin meiltä kysytään silloin tällöin mitä hyötyä yritykselle on siitä, että se tekee sopimuksen PYR:n kanssa. Vastaus on, että sopimuksen tehnyt yritys huolehtii valtioneuvoston päätöksessä säädetystä pakkausten hyötykäyttövelvoitteesta siirtämällä sen PYR:n kautta tuottajayhteisöille. Tällöin yrityksen ei tarvitse itse järjestää markkinoille toimittamiensa pakkausten hyötykäyttöä. Ongelma on siinä, että hyötykäytön järjestäminen on useimmiten yritykselle mahdoton tehtävä - -

Myös esimerkissä (9) simuloidaan yleistetyn lukijan ennakoitua kysymystä. Tässä kysymys kohdistuu eksplisiittisesti tekstin muotoon ja tulkintaan. Väliotsikossa evaluoidaan yrityksen vision muotoilua positiivisella ilmauksella bienoja sanoja, mutta sen tulkintaan ja konkreettisiin seurauksiin kohdistetaan epäilys (entäpäkäytännössä?).

(9) OpusCapitan visio on tulla johtavaksi rahaliikenteen ja likviditeetinhallinnan sovellusten ja asiantuntijapalveluiden tarjoajaksi Euroopassa.

Hienoja sanoja - entäpä käytännössä? 
Epäilys voi kohdistua yrityksen vision kuvauksen kahteen erilaiseen tulkinnalliseen ulottuvuuteen. Yhtäältä se kyseenalaistaa tämän propositionaalisen kuvauksen ehdot: sanallisen muotoilun ja sen kohteena olevan asiaintilan välisen suhteen. Vastaavatko "hienot sanat" yrityksen todellisia pyrkimyksiä? Toisaalta se kyseenalaistaa propositionaalisen kuvauksen seuraukset: yrityksen sanallisen sitoumuksen ja sen praktisten seurausten välisen suhteen. Mitä "hienojen sanojen" mukaisesta toiminnasta todella seuraa? Tekstissä siis varaudutaan yhtäältä siihen, että lukija kokee vision muotoilun - esimerkiksi sen sisältämän positiivisen evaluoinnin - liioitelluksi tai epäuskottavaksi, ja toisaalta siihen, että lukija ei pelkän abstraktin kiteytyksen perusteella vakuutu yrityksen vision hyödyllisyydestä käytännön toiminnan tasolla. Molemmat vaihtoehdot pyritään kumoamaan väliotsikkoa seuraavassa osiossa, jossa konkretisoidaan yrityksen pyrkimyksiä ja toimintaa.

Kahdessa jälkimmäisessä esimerkissä (10) ja (11) puolestaan selvennetään yksittäisten ilmausten merkityksiä metalingvistisen analyysin avulla. Esimerkin (10) toisessa virkkeessä nostetaan puheeksi edellisessä virkkeessä käytetyn positiivisesti evaluoivan ilmauksen onnellinen lapsuus käytön ehdot ja seuraukset. Pohdinnassa tunnustetaan ensin ilmauksen merkityksen sosiaalinen ja kulttuurinen variaatio erilaisten arvohierarkioiden mukaan. Tämän jälkeen abstrahoidaan eri merkitysten yhteistä ydintä eli ilmauksen käytön välttämättömiä ehtoja. Samalla implikoidaan, että juuri tässä merkityksessä ilmaukseen sitoudutaan tässä tekstissä. Ilmaus siis määritellään tavalla, joka yhtäältä palvelee tekstin tuottajan tarpeita mutta toisaalta pyrkii vetomaan mahdollisimman suureen osaan vastaanottajista.

\section{(10) Missio \& Visio}

Kaikki vanhemmat haluavat lapsilleen onnellisen lapsuuden. Se, mitä "onnel- linen lapsuus" tarkoittaa, vaihtelee perheestä toiseen ja kulttuurista toiseen - sekä aikakaudesta toiseen. Yhtäläisyyksiä on kuitenkin. Turvallisen kasvuympäristön tarjoaminen lapselle, sekä huolehtiminen siitä, että lapsi saa kulloisiaankin tarpeitaan kehittäviä toimintoja, ovat yhteistä kaikille vanhemmille.

\section{Hyvät lelut}

BRIO haluaa olla mukana tukemassa lapsen kehitystä tarjoamalla oikeanlaisia leluja aktivoimaan lasta leikin keinoin. Vahvan tietotaidon avulla BRIO kehittää leluja, jotka tuovat lapselle leikin iloa ja samalla tyydyttävät hänen tarpeitaan eri kehitysvaiheissa. BRIO on siis vanhempien luotettava "kumppani", tuki lapsen kasvattamisessa ja kehittymisessä. - -

Myös toinen kappale sisältää lainausmerkein erotetun ilmauksen ("kumppani"). Tässä tapauksessa ilmausta ei kuitenkaan ole poimittu edeltävästä tekstistä. Sen sijaan edellä on yrityksen pyrkimysten ja niitä toteuttavan konkreettisen toiminnan kuvauksia. Tämän jälkeen siis-partikkelilla johtopäätökseksi merkityssä lauseessa yritys nimeää itsensä rooliltaan vanhempien luotettavaksi "kumppaniksi". Edellä esitetty kuvaus siis toimii perusteluna käytetylle roolinimitykselle, minkä lisäksi nimitystä seuraa vielä selventävä apposition kaltainen lisäys (vanhempien luotettava "kumppani", tuki lapsen kasvattamisessa ja kehittymisessä). Tekstin rakenne toisin sanoen rationalisoi tekstin taustalla olevaa päättelyprosessia eli sitä, miten yritys muotoilee omia pyrkimyksiään: mitä kumppanilla tarkoitetaan ja miksi yritys sitoutuu juuri tällaiseen kuvaukseen. Lainausmerkein erotetun ilmauksen voi nähdä myös rekontekstualisaatio-ohjeena, jolla kehotetaan myös toisia käyttämään yrityksestä juuri tällaista kuvausta. Toisaalta lainausmerkkien käytöllä 
ilmennetään joskus epävarmuutta kielellisen valinnan sopivuudesta. Lainausmerkein voidaan ottaa etäisyyttä vakiintuneeseen kielenainekseen ja ilmaista, että sen tyypillinen käyttö ei täysin tavoita sitä, mitä kirjoittaja tässä tapauksessa ajaa takaa. Yhtä kaikki esimerkin (10) eksistentiaalisessa rationalisoinnissa ei luoteta keskeisten ilmausten väljiin yleiskielisiin merkityksiin, vaan ilmaukset määritellään ja sovitetaan harkitusti nimenomaan kyseiseen käyttöyhteyteen sopiviksi. ${ }^{11}$

Käytettyjen ilmausten määritteleminen suhteessa erilaisiin kulttuurisiin olettamuksiin ja arvohierarkioihin samoin kuin toivottujen puhetapojen tarjoaminen näkyvät vielä monisyisemmin esimerkissä (11). Tekstissä rakennetaan intertekstuaalinen suhde yrityksen toiseen tekstiin ("Visio-70"), josta on poimittu ja upotettu osaksi tätä tekstiä neljä yrityksen ihanteita kuvaavaa NP:tä. Teksti siis käsittelee ihanteita, jotka on asetettu ja muotoiltu toisaalla, eräänlaisena auktoriteettina näyttäytyvässä toisessa tekstissä.

(11) - - olemme luoneet yrityksellemme uuden vision, joka on nimeltään "Visio-70". Se ilmaisee ihanteita, joihin meidän pitää pyrkiä lähestyessämme yrityksemme 70. vuosijuhlaa vuonna 2010: "Mobiili-infoviihteellä” tarkoitetaan ympäristöä, jossa ihmiset voivat nauttia autoissaan äänentoistosta ja informaatiosta. Tulemme kehittämään tähän ympäristöön tuotteita, jotka korostavat "raikasta turvallisuuden tunnetta" ja "raikasta iloa" ja tekevät asiakkaistamme innostuneita

11 Tällaisten tapausten voi ajatella myös heijastavan visio-, missio- ja strategiatekstien yleistä taipumusta määritelmällisyyteen (ks. Drohan, 1999; Falsey, 1989; Pälli, Vaara \& Sorsa, 2009; Visakko, 2018; Williams, 2008). Myös tekstien tuottajille suunnatuissa kirjoitusohjeissa ihanteena on pidetty sekä tarkkuutta että ytimekkyyttä (ks. esim. Drohan, 1999; myös Ilvessalo \& Voutilainen, 2009), joskin nämä vaatimukset ovat helposti ristiriidassa keskenään. ja tyytyväisiä.

Tulevaisuudessa “arvokas yritys” ei pyri pelkästään tekemään voittoa, sillä yritys pyrkii myös täyttämään yrityksen kaikki velvollisuudet, olemaan yhteiskunnan sekä tietysti myös asiakkaidensa luottamuksen arvoinen ja olemaan korvaamattoman yrityksen maineessa.

Erityisen kuvaava on tekstin toinen kappale, jossa tarkennetaan ihanteen "arvokas yritys" sisältöä kieltomuotoisessa yhdyslauseessa (Tulevaisuudessa "arvokas yritys" ei pyripelkästään tekemään voittoa, sillä...). Kieltolause antaa ymmärtää, että vastakkainen sitoumus - se, että kyseinen yritys tai yritykset ylipäänsä pyrkisivät tekemään pelkästään voittoa - olisi jonkin vallitsevan olettamuksen mukaan odotuksenmukainen (ks. myös Kotilainen 2007, s. 16-29). Teksti ei kiistä, etteikö yritys pyrkisi tekemään voittoa, vaan päinvastoin samalla vahvistaa tämän oletuksen. Sen sijaan teksti pyrkii kumoamaan fokuspartikkelin pelkästään rajaavan merkityksen. Tarkoituksena on osoittaa, että "arvokkaalla yrityksellä" on muitakin päämääriä: perusteleva sillä-lause kuvaa erilaisia asiakasta ja yhteiskuntaa hyödyttäviä pyrkimyksiä, joihin yritys on sitoutunut. Käytetyllä ilmauksella (arvokas yritys) osoitetaan olevan kaksi puolta: perinteisen voittokeskeisen tulkinnan lisäksi se voidaan ymmärtää myös asiakkaan ja yhteiskunnan edun näkökulmasta. Tekstissä toisin sanoen sovitellaan yhteen kahta erilaista kulttuurista epistemologiaa ja arvomaailmaa. Diskursiivisella tasolla rakennetaan uusia käyttöyhteyksiä sijoittamalla NP:tä arvokas yritys uudenlaisiin lausekehyksiin (täyttää kaikki velvollisuudet; olla luottamuksen arvoinen jne.). Tekstissä tarjotaan siis konkreettisesti uudenlaisia puhumisen malleja. Lisäksi tekstissä kaiutetaan asiakkaiden ja muiden yhteiskunnallisten toimijoiden ääntä: olla 
[korvaamattoman yrityksen] maineessa -rakenteella yritys ilmaisee toiveensa siitä, millä vakiintuneella ilmauksella se toivoisi itseensä viitattavan ulkopuolisten keskuudessa (vrt. Fairclough, 1992, s. 120-121). Esimerkissä (11) käydään toisin sanoen monitasoista dialogia 1) auktoritatiivisen yritystekstin ("Visio-70"), 2) yrityksiä koskevien vallitsevien olettamusten ("pelkästään voittoa") ja 3) tässä juurrutettavien uusien, toivottujen olettamusten (mm. "yhteiskunnallisten velvoitteiden täyttäminen") sekä 4) toisten kuviteltujen puheiden ("korvaamaton yritys") välillä ja pyritään sommittelemaan ne koherentiksi kokonaisuudeksi.

\section{SLOGANIT, DISKURSIIVISET TRADITIOT JA KULTTUURINEN JATKUVUUS}

Viimeinen tapausryhmä koostuu teksteistä, joissa tekstin ydin - vision, mission tai strategian keskeisen sisällön tiivistävä ilmaus - on eksplisiittisesti erotettu ympäröivästä tekstistä niin, että se aktivoi kysymyksen tekstin eri ainesten lähteistä ja hierarkkisista suhteista. Metadiskursiivisten signaalien avulla ydinaineksen implikoidaan olevan muodoltaan vakiintunut tai vakiinnutettava eli peräisin jostakin kulttuurisesta traditiosta tai jatkumosta, josta se on jäljennetty kyseiseen tekstiin. Muu teksti puolestaan palvelee ydinaineksen tulkintaa ja välittämistä.

Visio-, missio- ja strategiateksteille on ylipäänsä luonteenomaista deduktiivinen rakentuminen, eteneminen kiteyttävistä yleistyksistä hierarkkisesti kohti yksityiskohtaisempia muotoiluja (ks. Visakko, 2018). Tekstit alkavat prototyyppisesti identifioivalla kopulalauseella, joka tiivistää yrityksen vision, mission tai strategian esimerkiksi yhteen infinitiivi(12) tai substantiivilausekkeeseen (13):

(12) Axession Finlandin strategiana on auttaa B2B-sektorilla toimivia asiantuntijaorganisaatioita menestymään omassa myyntityössään.

(13) Veritas-ryhmän missio on turvallisuuden luominen.

Rakenteet identifioivat tietyn lausekkeen (InfP tai NP) tietyntyyppiseksi yrityskulttuurin normien sääntelemäksi diskursiiviseksi entiteetiksi (visioksi,missioksi tai strategiaksi), jollaisia yrityksellä voi käytännössä olla kutakin vain yksi kerrallaan. Jo tällaisissa perustapauksissa siis vision, mission tai strategian kuvauksen tiivistäminen yhteen nominaaliseen lausekkeeseen antaa vaikutelman, että kyse on uniikista, muodoltaan harkitusta ja vakiinnutetusta kokonaisuudesta, joka esiintyy tai voisi esiintyä samassa muodossa kaikissa esiintymiskonteksteissaan.

Seuraavissa esimerkeissä tekstin ydin on lisäksi erotettu muusta tekstistä itsenäiseksi kokonaisuudeksi, jolloin kyseinen aines näyttäytyy vielä selvemmin määrämuotoon kiteytyneenä. Esimerkeissä (14) ja (15) on käytetty lainausmerkkejä, kun taas esimerkissä (16) kiteytys on lihavoitu ja erikielinen kuin ympäröivä teksti:

(14) Strategiamme on: "Pitkäaikaisen kokemuksen, teorian ja omakohtaisten tutkimusten tuomalla osaamisella Asiakaslähtöisiin tarpeisiin käyttäen sopivia menetelmiä ja vahvaa kyseenalaistamista"

(15) Väestöliiton missio on "Terve, turvallinen ja tasa-painoinen elämä alkaa perheestä ja vaikuttaa koko yhteiskuntaan".

(16) Visiomme on Delivering More.

- Se tarkoittaa venymistä huippusuorituksiin, riman nostamista, uusien ratkaisujen etsimistä, pyrkimystä olla 
edelläkävijä.

- Se on positiivista asennetta, vastuun ottamista ja välittämistä

- Se on luottamista omiin kykyihimme.

- Delivering More saa meidät erottumaan eduksemme.

Esimerkeissä (14) ja (15) kiteytys ei ole muodoltaan mukautunut hallitsevan lauseen syntaktiseen rakenteeseen (ja sen integroiminen siihen edellyttäisi esimerkiksi konjunktion tai verbin lisäämistä). Esimerkissä (16) taas morfosyntaktisen koodin vaihtuminen ja typografinen korostus signaloivat, että aineksen tuominen juuri tässä muodossa tekstiin on olennaista. Kyse onkin kansainvälisen yrityksen sloganista, joka on kopioitu kyseiseen tekstiin selittämistä ja tulkintaa varten (vrt. esim. 9-11).

Metadiskursiivinen kehystys viestii kaikissa näissä esimerkeissä, että jokin vakiintunut muotoilu on toistettu sellaisenaan ja sidottu tekstin merkitysrakenteeseen. Toisin sanoen teksti rekontekstualisoi jonkin aineksen yrityksen omasta diskursiivisesta traditiosta ja samalla välittää tämän aineksen edelleen lukijoilleen uusissa diskursivisissa tapahtumissa. Tekstissä siis mallinnetaan intertekstuaalista ketjua menneisyydestä kyseisen tekstin kautta tulevaisuuteen. Koska jäljennetty aines näyttäytyy koko tekstin ydinsisältönä ja tekstissä orientoidutaan sen muodon tarkkaan toistamiseen ja tulkintaan, alkuperäinen lähde hahmottuu helposti auktoriteetin kaltaiseksi (ks. myös Bauman \& Briggs, 1990, s. 77; Urban, 1996, s. 37-40). Samanaikaisesti tekstin tuottaja itsekin sitoutuu jäljennettyyn ja rekontekstualisoituun sisältöön. Tekstin tuottajan ääni ja välitetty auktoritatiivinen ääni toisin sanoen sulautuvat yhteen. Diskurssin välittämistä ja erityisesti kielellisen muodon tarkkaan toistamiseen orientoitumista esimerkiksi valoissa, myyttien kerronnassa tai muissa rituaalisissa konteksteissa on pidetty yhtenä keskeisenä tapana tuottaa kulttuurista jatkuvuutta (ks. Urban, 1991). Edellä käsitellyt tapauksetkin voi nähdä osana traditionalisointiprosessia, jossa symbolisesti tuotetaan yrityskulttuurin jatkuvuutta (ks. myös Bauman \& Briggs, 1990, s. 78; Eisenlohr, 2010, s. 321). ${ }^{12}$ Visio-, missio- ja strategiatekstit näyttäytyvät alustana, jonka avulla voidaan vakiinnuttaa, muokata ja levittää diskursiivisia aineksia edelleen toisiin konteksteihin.

Viimeinen käsiteltävä tapaus eroaa osittain edellisistä mutta havainnollistaa samoja ilmiöitä. Esimerkissä (17) otsikko nimeää ensin tekstin visioksi (Visiomme). Leipäteksti alkaa tyypillisellä kiteyttävällä määritelmällä, jossa vision parafraasina toimii ilmaus tavoitteemme. Kiinnostavaa on, että tämän jälkeen samaa ketjua jatketaan vielä kerran uudella, lainausmerkein erotetulla muotoilulla. Se kehystetään johtoilmauksella, jonka pronominiviittaus kytkee jäljessä seuraavan aineksen edeltäviin ilmauksiin (Ilmaisemme sen [= tavoitteemme $=$ visiomme $]$ nyt seuraavalla tavalla). Samalla johtoilmaus kiinnittää huomiota ilmaisemisen tapaan ja ankkuroi sen ajallisesti (Ilmaisemme sen nyt $\mid$ seuraavalla tavalla). Tavallaan näin korostetaan kyseisen kielellisen muotoilun hetkellisyyttä ja kytköstä käsillä olevaan puhetilanteeseen ja nytadverbin rajaamaan ajanjaksoon. Toisaalta samalla johtoilmaus nimenomaan ilmentää ajallista jatkuvuutta ja traditiota: kyse on sisällöstä, jonka kielellinen muotoilu voi elää mutta on toistaiseksi sidottu juuri tähän ilmaisemisen tapaan. Aines siis kehystetään jälleen yhdeksi, juuri tähän tilanteeseen sovitetuksi rekontekstualisoinniksi.

12 Yrityksen historian ja pysyvyyden korostamista on myös pidetty yhtenä retorisena keinona luottamuksen herättämiseksi yritysviestinnässä ( $k s$. esim. Van De Mieroop, 2008, s. 503). 


\section{(17) Visiomme}

Tavoitteemme on vakuuttaa ihmiset kaikkialla maailmassa siitä, että VELUX kattoikkunat ovat ihanteellisen asuin- ja työympäristön perusta.

Ilmaisemme sen nyt seuraavalla tavalla: "Tuomalla kattoikkunoiden kautta päivänvaloa ja raikasta ilmaa haluamme olla entistä parempien asuinympäristöjen johtava kehittäjä ja asiakkaidemme mielestä paras."

Kiinnostavaa esimerkissä on joka tapauksessa se, mitä tekstin metadiskursiiviset signaalit paljastavat vision muodon ja sisällön suhteesta. Tekstissä kuvataan ensin vision keskeistä sisältöä (Tavoitteemme on vakuuttaa - -). Tämän jälkeen sisältö kiteytetään vielä aivan erityiseen muotoon. Visiolla on tekstissä siis kaksi toisistaan eriytynyttä kiteytystä, joista ensimmäisessä korostuu sisältö (propositionaalinen painotus) ja jälkimmäisessä muotoilu (poeettinen painotus). Jälkimmäinen saa performatiivisen kehystyksen, joka spesifioi kielellisen toiminnan luonnetta ja asettaa sen arvioinnin alaiseksi. Se saakin estetisoidun ja tarkkaan harkitun lupauksen sävyn (vrt. esim. valoihin ja vannomisiin). Teksti jäsentää ja kommentoi itseään tavalla, joka korostaa auktoritatiivisen tradition ja poeettisen muotoilun merkitystä eksistentiaalisessa rationalisoinnissa.

\section{EKSISTENTIAALINEN \\ RATIONAALISUUS JA MONIÄÄNISYYDEN HALLINNAN MUODOT}

Artikkelissa on analysoitu sitä, millaisilla rakenteilla yritysten verkkosivujen visio-, missio- ja strategiateksteissä asennoidutaan toisiin ääniin ja kontrolloidaan moniäänisyyttä. Rakenteiden tarkasteleminen pelkästään moniäänisyyden tai intertekstuaalisuuden näkö- kulmasta ei kuitenkaan kerro paljoa niiden perimmäisistä funktioista. Tutkimuksen tarkoituksena on ollut osoittaa, miten kyseiset rakenteet - yhdessä monien muiden rakenteiden kanssa (ks. Visakko, 2018) - toimivat keinoina jäsentää yrityksen identiteettiä osana sekä yrityksen sisäistä että yrityksen ja sen toimintaympäristöjen välistä sosiaalista toimintaa. Tällainen eksistentiaaliseksi rationaalisuudeksi nimitetty toiminnan laji onkin funktionaalinen kategoria, joka kattaa niin tekstilajin yleiset päämäärät kuin sen puitteissa toteutuvat yksityisemmät tarkoitusperät (vrt. Bhatia, 2004) - sekä näiden keskinäiset konfliktit.

Käsitellyissä esimerkeissä avoin moniäänisyys on liittynyt 1) ongelmien, auktoriteetin ja empatian esittämiseen, 2) institutionaalisten ja henkilökohtaisten näkökulmien suhteuttamiseen, 3) haitallisten olettamusten ja ennakkoluulojen käsittelyyn, 4) ilmausten määrittelyyn ja lukijoiden reaktioiden ennakoimiseen sekä 5) diskursiivisten traditioiden välittämiseen. Näin ryhmiteltynä tapaukset heijastavat pitkälti nimenomaan kyseisten tekstilajien funktioita. Lisäksi eri tapausryhmissä yhdistyy usein erilaisia moniäänisyyden hallintamuotoja. Näiden ryhmien pohjalta voidaankin abstrahoida vielä yleisempiä kuvauksia niistä perustavista tavoista, joilla toisiin ääniin on mahdollista asennoitua eksistentiaalisessa rationalisoinnissa ja joita voidaan peilata myös muunlaisiin aineistoihin (ks. Taulukko 2).

Aineiston tekstit eivät useinkaan näytä pyrkivän kielelliseen tuoreuteen tai omaperäisyyteen, mitä on pidetty tyypillisenä monille promotionaalisille teksteille, erityisesti mainoksille (ks. esim. Halmari \& Virtanen, 2005). Pikemminkin yrityskulttuurin elinvoimaisuutta ilmennetään osoittamalla yritystä ohjaavien auktoritatiivisten periaatteiden perinteisyyttä, vakiintuneisuutta ja harkittuutta. Lisäksi teksteissä voidaan päästää ääneen 
toimitusjohtaja tai jokin muu asiantuntijaauktoriteetti. Erilaisten traditionaalisten ja auktoritatiivisten äänten välittäminen ja tul- kitseminen näyttäytyykin aineiston valossa aivan erityisenä moniäänisyyden hallinnan muotona (1).

Taulukko 2. Moniäänisyyden hallinnan muotoja.

1. Traditionaalisten ja auktoritatiivisten äänten välittäminen ja tulkitseminen.

2. Äänten metalingvistiset reflektiot, paralleelit ja suhteutukset.

3. Positiivisten (omien tai toisten) äänten tarjoaminen rekontekstualisoitavaksi.

4. Negatiivisten (toisten) äänten kumoaminen tai neutralisoiminen.

Aineiston teksteissä pohditaan ja määritellään ilmausten käytön ehtoja ja seurauksia. Esimerkiksi leluvalmistajan tarjoama onnellinen lapsuus vaikuttaa ilmauksen eri käyttötapoja eri yhteisöissä ruotivan metalingvistisen pohdinnan ansiosta tarkkaan perustellulta arviolta eikä tyhjältä mainosretoriikalta. Lisäksi teksteissä rinnastetaan ja sovitellaan toisiinsa erilaisia diskursiivisia näkökulmia ja intressejä (esim. institutionaalinen vs. yleisinhimillinen; taloudellinen vs. yhteiskunnallinen). Teksteissä voidaan siis monin eri tavoin nostaa huomion kohteeksi diskursiivisen muotoilun suhde sen välittämiin merkityksiin ja sitoumuksiin. Toisena merkittävänä moniäänisyyden hallinnan keinona voidaankin pitää metalingvistisiä reflektioita ja paralleeleja, joilla voidaan sovittaa ja suhteuttaa toisiinsa erilaisia ääniä (2).

Odotuksenmukaista on, että promotionaalisissa teksteissä esitetään tekstin tuottajan kannalta positiivisia näkökulmia. Usein moniäänisyyden hallintaan liittyy kuitenkin myös pyrkimys tarjota suotuisia diskursiivisia aineksia levitettäväksi (3). Ilmaus voidaan esimerkiksi muotoilla ytimekkäästi sloganin kaltaiseksi ja nostaa kohosteiseen tekstiasemaan, josta se on helpommin rekonteks- tualisoitavissa. Toisaalta teksteissä voidaan kaiuttaa eri tahojen aiempia tai ennakoituja sanoja ja tarjota lukijalle valmiita ilmauksia omaksuttaviksi. Tekstiin kirjoittuu näin useita erillisiä, ikään kuin toisistaan riippumattomia positiivisia ääniä.

Vaikka promotionaalisille diskursseille on pidetty tyypillisenä monologista positiivisuutta (ks. Bhatia, 2004, 2005), kyse on pikemminkin jatkuvasta kamppailusta jonkin kohteen julkisesta representaatiosta toisia ääniä vastaan. Tämän tutkimuksen perusteella niin eksistentiaalisen rationaalisuuden kuin promotionaalisen diskurssin yksi tunnuspiirre onkin aktiivinen oman äänen suhteuttaminen kilpaileviin ääniin, myös ei-toivottuihin. Dialogia voidaan käydä sellaisten äänten kanssa, jotka tekstin tuottaja ymmärtää haitallisiksi tai ongelmallisiksi. Toisaalta teksteissä voidaan myös ennakoida ja pyrkiä ehkäisemään lukijoiden epätoivottuja tulkintoja. Tällaiset negatiiviset äänet voidaan integroida hallitusti tekstuaalisiin rakenteisiin, joissa ne pyritään kumoamaan tai neutralisoimaan (4). Tällaista argumentointia on kutsuttu dissosiatiiviseksi: sen päämääränä on purkaa vakiintuneita kytköksiä käsitteiden, uskomusten tai olettamusten välillä 
(ks. Perelman, 2002 [1977], s. 159-171). Erilaisten vastaväitteiden ja kilpailevien näkemysten ennakoinnin ja käsittelyn on jo sinänsä ajateltu lisäävän argumentoinnin harkittuuden ja avoimuuden vaikutelmaa (mts. 173-180). Vastakkaisen näkemyksen kanssa väittelevää dialektista performanssia voi pitää eräänlaisena varmuuden näyttelemisenä (ks. Fairclough, 2000, s. 178). Kahden äänen vastakkainasettelu on lavastettu verbaalinen mittely, jossa ei neuvotella ainoastaan väitteiden paikkansapitävyydestä vaan rakennetaan sosiaalisia suhteita ja identiteettien rajoja (ks. myös Irvine, 2010; Pagliai, 2010).

Artikkelissa on täydennetty kuvaa yritysten visio-, missio- ja strategiateksteistä osoittamalla yksityiskohtaisesti, kuinka ne käyvät dialogia toisten äänten kanssa. Ne pyrkivät samalla joko hidastamaan tai kiihdyttämään erilaisten diskursiivisten ainesten liikettä ja sovittelemaan niitä toisiinsa harmonisesti. $\mathrm{Ne}$ pyrkivät siis toimimaan metakulttuurisena voimana (ks. Urban, 2001), joka ohjaa tekstien käyttäjäyhteisöjen puheita ja tulkintoja tiettyyn suuntaan. ${ }^{13}$ Kiinnostava jatkotutkimuksen aihe olisikin se, minkälaisia teksti- tai puheketjuja visio-, missio ja strategiatekstien pohjalta syntyy ja missä määrin tällaisia ketjuja todella onnistutaan ohjaamaan visio-, missio ja strategiatekstien diskursiivisilla

13 Bahtinilaisittain voisi ajatella, että kyse on erilaisten keskipakoisten ja keskihakuisten voimien jännitteestä (ks. Bakhtin, 1981, s. 270-272). Keskihakuisuutta on visio-, missio- ja strategiatekstien pyrkimys yhdenmukaistaa ja vakiinnuttaa yrityksen omien intressien mukaisia kuvauksia. Keskipakoisuutta puolestaan aiheuttaa diskursiivisten ainesten luonnollinen variaatio yhteisöissä ja muuntuminen käyttökontekstista toiseen. Toisaalta kilpailevat intressikeskukset (esim. yrityksen johto vs. yrityksen työntekijät, asiakkaat, media, poliitikot jne.) omine keskihakuisine voimineen ovat usein toisilleen keskipakoisten voimien lähteitä, sillä ne pyrkivät vakiinnuttamaan ja levittämään kilpailevia tai jopa toisensa poissulkevia kuvauksia. Esimerkiksi dialogi haitallisten äänten kanssa on eräänlainen pyrkimys aiheuttaa hajaannusta toisiin keskuksiin (esim. jossain yhteisössä vallitseviin käsityksiin). valinnoilla. Erityisesti artikkelissa on pyritty osoittamaan, että yritysviestinnän lisäksi tekstien voi nähdä ilmentävän yleisinhimillisiä semioottisia prosesseja, kuten eksistentiaalista rationaalisuutta, joka kytkee ne moniin muihin minuuden ja maailman suhdetta reflektoiviin diskursseihin. Lisäksi huomiota on kiinnitetty visio-, missio ja strategiatekstien poeettiseen puoleen. Yritysten verkkosivujen visio-, missio- ja strategiatekstien eksistentiaaliselle rationalisoinnille ei ole olennaista pelkästään se, miten niissä kuvaillaan yrityksen pyrkimyksiä ja suhteita toisiin toimijoihin, vaan myös se, kuka teksteissä puhuu ja millä tavalla. Yksilöiden tavoin yritykset hakevat omaa kirjallista ääntään: tunnistettavaa ja esteettisesti vaikuttavaa tyyliä.

\section{LÄHTEET}

Agha, A. (2005). Voice, footing, enregisterment. Journal of Linguistic Anthropology, 15, 38-59.

Agha, A. (2007). Language and social relations. Cambridge: Cambridge University Press.

Bakhtin, M. (1981). Discourse in the novel. Teoksessa M. Holquist (toim.), The dialogic imagination, (s. 269-434). Austin: University of Texas Press.

Bakhtin, M. (1986). The problem of speech genres. Teoksessa C. Emerson \& M. Holquist (toim.), M.M. Bakbtin, speech genres and other late essays, (s. 60-102). Austin: University of Texas Press.

Bartkus, B., Glassman M. \& McAfee B. (2000). Mission statements: Are they smoke and mirrors? Business Horizons, 43 (6), 23-29.

Bauman, R. \& Briggs C. (1990). Poetics and performance as critical perspectives on language and social life. Annual Review of Anthropology, 19, 59-88.

Bhatia, V. (1993). Analysing genre: Language use in professional settings. Lontoo: Longman.

Bhatia, V. (2004). Worlds of written discourse: $A$ genre-based view. Lontoo: Continuum.

Bhatia, V. (2005). Generic patterns in promotional discourse. Teoksessa H. Halmari \& T. Virtanen (toim.), Persuasion across genres, (s. 
213-225). Amsterdam: John Benjamins.

Bhatia, V. (2008). Genre analysis, ESP and professional practice. English for Specific Purposes, 27, 161-174.

Brandom, R. (2000). Articulating reasons. An introduction to inferentialism. Cambridge: Harvard University Press.

Briggs, C. \& Bauman, R. (1992). Genre, intertextuality and social power. Journal of Linguistic Anthropology, 2, 131-172.

Drohan, W. (1999). Writing a mission statement. Association Management, 51, 117.

Eisenlohr, P. (2010). Materialities of entextualization: The domestication of sound reproduction in Mauritian muslim devotional practices. Journal of Linguistic Anthropology, 20, 314-333.

Fairclough, N. (1992). Discourse and social change. Cambridge: Polity Press.

Fairclough, N. (2000). Discourse, social theory, and social research: The discourse of welfare reform. Journal of Sociolinguistics, 4, 163-195.

Falsey, T. (1989). Corporate philosophies and mission statements: A survey and guide for corporate communicators and management. Westport: Greenwood Press.

Halmari, H. \& Virtanen, T. (2005). Towards understanding modern persuasion. Teoksessa H. Halmari \& T. Virtanen (toim.), Persuasion across genres, (s. 229-244). Amsterdam: John Benjamins.

Heikkinen, V. (2000). Tekstuaalinen pirunnyrkki. Teoksessa V. Heikkinen, P. Hiidenmaa \& U. Tiililä (toim.), Teksti työnä virka kielenä, (s. 63-115). Helsinki: Gaudeamus.

Hoey, M. (1983). On the surface of discourse. Lontoo: Allen \& Unwin.

Hoey, M. (2001). Textual interaction: An introduction to written discourse analysis. Lontoo: Routledge.

Holleman, B. \& Pander Maat, H. (2009). The pragmatics of profiling: Framing effects in text interpretation and text production. Journal of Pragmatics, 41, 2204-2221.

Ilvessalo, S. \& Voutilainen, R. (2009). Näkökulmia vakuutusliiketoiminnan strategiseen jobtamiseen. Helsinki: Finanssi- ja vakuutuskustannus $\mathrm{Oy}$.

Irvine, J. (1996). Shadow conversations: The indeterminancy of participant roles. Teoksessa M. Silverstein \& G. Urban (toim.), Natural histories of discourse, (s. 131-159). Chicago: University of Chicago.

Irvine, J. (2010). Afterword: Disputing consensus. Journal of Linguistic Anthropology, 20, 214-224.

ISK = Hakulinen, A., Vilkuna, M., Korhonen, R., Koivisto, V., Heinonen, T. \& Alho, I. (2004). Iso suomen kielioppi. Helsinki: SKS.

Kockelman, P. (2004). Stance and subjectivity. Journal of Linguistic Anthropology, 14, 127 150.

Kockelman, P. (2006). Representations of the world: Memories, perceptions, beliefs, intentions, and plans. Semiotica, 162, 73-125.

Kockelman, P. (2013). Agent, person, subject, self. A theory of ontology, interaction, and infrastructure. New York: Oxford University Press.

Kotilainen, L. (2007). Kiellon lumo. Kieltoverbitön kieltokonstruktio ja sen kiteytyminen. Helsinki: SKS.

Kuikka, L. (2009). Lehtimainoksen multimodaalisuus. Teoksessa V. Heikkinen (toim.), Kielen piirteet ja tekstilajit, (s. 37-62). Helsinki: SKS.

Laitinen, L. (1995). Nollapersoona. Virittäjä, 99, 337-358.

Lozachmeur, Ghislaine (2007). Les modes d'enchaînement syntaxiques dans le texte publicitaire. Teoksessa D. Banks (toim.), La coordination et la subordination dans le texte de spécialité, (s. 123-141). Pariisi: L'Harmattan.

Lyons, J. (1977). Semantics. (Vol. 2). Cambridge: Cambridge University Press.

Mäntynen, A. (2003). Miten kielestä kerrotaan. Kielijuttujen retoriikkaa. Helsinki: SKS.

Pagliai, V. (2010). Introduction: Performing disputes. Journal of Linguistic Anthropology, 20, 63-71.

Perelman, C. (2002) [1977]. Lempire rhétorique. Pariisi: Librairie philosophique J. Vrin.

Pälli, P., Vaara, E. \& Sorsa, V. (2009). Strategy as text and discursive practice: a genre-based approach to strategizing in city administration. Discourse \& Communication, 3, 303-318.

Shore, S. (2005). Referoinnista projektioon ja metarepresentaatioon. Teoksessa M. Haakana \& J. Kalliokoski (toim.), Referointi ja moniä̈nisyys, (s. 44-82). Helsinki: SKS.

Silverstein, M. \& Urban, G. (1996). The natural history of discourse. Teoksessa M. Silverstein \& G. Urban (toim.), Natural Histories of Discourse, 
(s. 1-17). Chicago: University of Chicago.

Solin, A. (2004). Intertextuality as mediation: On the analysis of intertextual relations in public discourse. Text, 24, 267-297.

Solin, A. (2006). Genre ja intertekstuaalisuus. Teoksessa A. Mäntynen, A. Solin \& S. Shore (toim.), Genre - Tekstilaji, (s. 72-95). Helsinki: SKS.

Solin, A. (2010). Kriittinen diskurssintutkimus. Teoksessa V. Heikkinen, E. Voutilainen, P. Lauerma, U. Tiililä \& M. Lounela (toim.), Genreanalyysi, (s. 558-563). Helsinki: Gaudeamus.

Swales, J. (1990). Genre analysis. English in academic and research settings. Cambridge: Cambridge University Press.

Swales, J. \& Rogers, P. (1995). Discourse and the projection of corporate culture: The mission statement. Discourse \& Society, 6, 223-242.

Urban, G. (1991). A discourse-centered approach to culture. Austin: University of Texas Press.

Urban, G. (1996). Entextualization, replication, and power. Teoksessa M. Silverstein \& G. Urban 1996 (toim.), Natural histories of discourse, (s. 21-44). Chicago: University of Chicago.

Urban, G. (2001). Metaculture. How culture moves through the world. Minneapolis: University of Minnesota Press.

Van De Mieroop, D. (2008). Co-constructing identities in speeches: How the construction of an 'other' identity is defining for the 'self' identity and vice versa. Pragmatics, 18, 491-509.

Virsu, V. (2012). Sitouttamisretoriikka yritysviestinnässä. Turku: Turun yliopisto.

Visakko, T. (2015). Self-promotion as semiotic behavior. The mediation of personhood in light of Finnish online dating advertisements. Helsinki: Helsingin yliopisto.

Visakko, T. (2018). Päämäärät, ongelmat ja tilaisuudet. Eksistentiaalinen rationaalisuus ja kausaalis-evaluatiiviset diskurssikuviot yritysten verkkosivujen visio-, missio- ja strategiateksteissä. Sananjalka, 60, 142-160.

Williams, L. (2008). The mission statement: A corporate reporting tool with a past, present, and future. Journal of Business Communication, 45, 94-119. 


\section{EXISTENTIAL RATIONALITY AND THE DIALECTIC OF ENTEXTUALIZED VOICES IN COMPANIES' VISION, MISSION, AND STRATEGY STATEMENTS}

Tomi Visakko, University of Helsinki

This article examines a process called existential rationality in visions, missions, and strategies on companies' websites. The aim is to understand how the companies publicly define and idealize their identities, intentions, and social relations in these texts. The article focuses on the explicit modelling and controlling of relationships between recognizable discursive voices. The analyses look at a set of morpho-syntactic constructions that denote or presuppose intertextual relations (e.g., reported speech, quotation marks, questions, negations) with the aim of understanding how such constructions are used in textual structures to signal the functions, sources, and mutual relations of entextualized voices. The main types of voice mediation identified in the article are the transmission of traditional and authoritative voices, the metalinguistic reflection and reconciliation of diverging voices, the dissemination of positive voices, and the invalidation or neutralization of negative voices.

Keywords: evaluation, intertextuality, metadiscourse, rationality, voice 